\author{
Katarzyna Danilewicz \\ Katolicki Uniwersytet Lubelski Jana Pawta II \\ https://orcid.org/0000-0003-2691-7880 \\ katarzyna.danilewicz@kul.pl
}

\title{
Phenomenon of Melodic Changes in the late Medieval Notation of Jan Olbracht Gradual on the Example of Antiphon ad Mandatum "Si ego Dominus et Magister"
}

The subject of the present paper is an analysis of melodic changes of the antiphon for Mandatum rite "Si ego Dominus et Magister” recorded in the Jan Olbracht Gradual, volume 1: De Sanctis (PL-Kk 43). The manuscript, located in the Archives and Library of the Cracow Cathedral Chapter, ${ }^{1}$ was created between 1499 and $1501^{2}$ and is one of the most valuable monuments of the late Middle Ages in Poland, containing a priceless record of liturgical and musical tradition of the Wawel Cathedral, which undoubtedly had its original shape. ${ }^{3}$ The analysis will be performed on the basis of comparison of the adiastematic record of the discussed antiphon in the $10^{\text {th }}$ century Hartker Antiphonary (CH-SGs 390) and its melodic restitution in Graduale Novum $(\mathrm{GrN}){ }^{4}$

The antiphon „Si ego Dominus et Magister” is one of several antiphons included in the Mandatum formulary for Maundy Thursday in PL-Kk 43. The ceremony of foot-washing itself has a very complex history. In the late Middle Ages,

1 The author would like to thank the Director of the Archives and Library of Cracow Cathedral Chapter, Fr. prof. dr hab. Jacek Urban for providing the access to Jan Olbracht Gradual (Chapter's siglum: AKKK, Ms. 43, RISM siglum: PL-Kk 43) and enabling the use of cards 197 and 197v for the purpose of this article.

2 See M. Popowska, Jan Olbracht Gradual from the Archives of the Wawel Cathedral. Physical description, „Edukacja Muzyczna” 13 (2018), p. 183-207, http://cejsh.icm.edu.pl/cejsh/element/ bwmeta1.element.mhp-624d66e0-ef05-4aef-85f0-7e88977f6e0c (25.06.2021).

3 For wider description of the monument see among others: T. Miazga, Graduat Jana Olbrachta. Studium muzykologiczne, Graz 1980; M. Popowska, Jan Olbracht Gradual, p. 183-207.

4 Graduale Novum, vol. 2: De feriis et sanctis, Regensburg 2018, p. 88. 
in diocesan liturgies, it was celebrated on Maundy Thursday after the Chrism Mass, joined with reduced Vespers, after the Stripping of the Altar, sometimes also after the Compline. ${ }^{5}$ The detailed course of the ceremony was characteristic of the centre where the ritual was performed. The Mandatum formulary used in medieval liturgies is quite heterogeneous. ${ }^{6}$ As Robert Amiet notes (referring to dioceses of France) individual dioceses gave the rite a specific character. ${ }^{7}$ Comparative studies of several dozen manuscripts from different parts of Europe show that one common "pool" of antiphons and verses was used (this applies to both the text and the melody), while their selection and order were specific to individual traditions. Establishing the "identity" of the Wawel tradition of the Mandatum ceremony requires extensive research, whereas the analysis of one of the antiphons might be a good example of how the Cracow Cathedral in the late Middle Ages could "adapt" the tradition that functioned in the Western Church.

The text of the antiphon in PL-Kk 43 is as follows: "Si ego dominus et magister vester lavi vobis pedes quanto magis vos debetis alter alterius lavare pedes" (J 13, 14).

English translation, after the Revised Standard Version of the Bible, Catholic Edition, reads: "If I then, your Lord and Teacher, have washed your feet, you also ought to wash one another's feet".

The literal translation is as follows: "If I, lord and teacher of yours, have washed feet to you, how much more you ought to, one to the other, wash feet".

The text of the chant, as with most of the antiphons found in the Mandatum formulary, comes from chapter 13 of the Gospel according to St. John, in which the evangelist describes the gesture of washing the feet of the apostles by Christ during the Last Supper. The text in PL-Kk 43 is exactly the same as in the Hartker Antiphonary. Let us see how the copyist of CH-SGs 390 - one of the monks of the Abbey of Saint Gall ${ }^{8}$ recorded the antiphon, bearing in mind the rhetorical function of adiastematic notation. ${ }^{9}$ We will use the detailed analysis of the

5 D. Hiley, Western plainchant: a handbook, Oxford 1993, p. 35.

6 See: R. Amiet, Le Mandatum de Jeudi Saint XIIIe-XVIIIe siècles, "Études Gregoriennes" 29 (2001), p. 68-87; J. Lewański, Liturgiczne tacińskie dramatyzacje Wielkiego Tygodnia $X I-X V I w$., Lublin 1999, p. 195-232; see also Manuscripts from CANTUS database and Bibliothèque Nationale de France.

7 R. Amiet, Le Mandatum, p. 69.

8 Traditionally, the authorship of the antiphonary is attributed to the monk Hartker, in fact, most likely four more copyists participated in the writing of the manuscript, see F.K. Praßl, Kodeks Hartkera (CH-SGs 390/391) - genialna szkota retoryki w stużbie teologii liturgicznej, „Pro Musica Sacra” 17 (2019), p. 47.

9 See F.K. Praßl, Kodeks Hartkera, p. 43-61. 
antiphon's notation in a later study of the melodic transformations of the version recorded in PL-Kk 43.

The restitution of the antiphon in $\mathrm{GrN}$, based on the record from CH-SGs 390 , is noted in the first mode (authentic protus), the structural sounds of which are the dominant $l a$ and the final $r e .{ }^{10}$ On the particle $S i$ we have a virga on the $m i$ sound, then on the syllable $e$-go a tractulus indicating a sound lower than the previous one, but also emphasizing a delicate stress on this syllable (it is a structural sound $r e$ ), and a virga on the e-go syllable on the mi sound. On the noun Dominus the melody rises, the copyist notes virga on the stressed syllable Do-, pes on the syllable $-m i$ which is progressively tending towards the structural sound $l a$, and virga strata on the syllable -nus. Virga strata is in this case two sounds in the unison, on the structural sound $l a$, indicating a connection with what will follow. The copyist clearly wants to show the connection between the words Dominus and Magister, emphasizing the role of Christ who speaks these words - He is our Lord and Teacher. All the sounds in the noun Dominus are flowing, and the final oriscus announces another lower note - on the conjunction $e t$. It also advises not to stop at this point, to move forward in the phrase, because the next noun Magister seems to be underlined in a special way. The melody on this word reaches its peak - the upper $r$, which has an ornamental function. On the syllable $M a$ - the copyist notes scandicus quilismaticus raising the melody to the structural sound of this part - do. The initial virga has an episeme, thus the copyist emphasizes the importance of the word and draws attention to its articulation. On the syllable -gis we have a virga and finally the torculus on the syllable -ter, on the sound $d o$. The ornamental middle sound of the torculus rises to the above-mentioned upper re. On the first syllable of the pronoun vester there is a four-note climacus with initial pulsating sound and first three non-flowing sounds, which slows the relaxation of the tension from upper do towards sol, prepared by non-flowing clivis. The words magister vester, meaning "your teacher", are especially emphasized by the copyist of the antiphonary. The articulation measures expressed in adiastemic neumes lead us to meditation on the person of Christ, who is not only our Lord, but above all our Teacher, whom we should imitate, of what the further part of the antiphon says. After a short relaxation on the cadence (in $\mathrm{GrN}$ we have divisio minima after the pronoun vester) the melody regains its tension. On the words lavi vobis pedes the sounds oscillate around the dominant $l a$, reaching the sound $d o$ on the syllable -bis. The copyist notes single-note neumes, virga and tractulus on each sound, only on the syllable -bis there is a clivis with significative letters: $s$ denoting sursum

10 See Fig. 1. Comparative table in Appendices. 
that is "up, with support," 11 also announcing another sound lower by semitone, and $c$ that is celeriter meaning: flowing, without articulation. The copyist clearly emphasizes the pronoun vobis, as if to point out that the Lord and Teacher humbled himself, became a servant having washed the feet of us sinners. In the noun pedes we have two tractuli on the dominant la that close the first part of the antiphon. Here we can see how much the melody and articulation are subordinate to the text and how they constitute its exegesis. The first part of the antiphon, the phrase "Si ego Dominus et Magister lavi vobis pedes", is also the first component of conditional sentence - the conditional clause. It is clearly marked in the composition of the melody which oscillates in the higher register. The second part, the main clause: "quanto magis vos debetis alter alterius lavare pedes" is the teaching we are to receive from Christ, our Teacher (this function is emphasized by the melody in the first part of the antiphon). Since this teaching is a call to humility and merciful love, and the text no longer speaks about Christ but about us, the melody goes consistently down to the final $r$. The rhetorical phrase quanto magis meaning "how much more" is also melodically decorated and emphasized by numerous episemes. The copyist begins the phrase with cephalicus on the dominant $l a$, reminding us to clearly pronounce the passage from the consonant " $\mathrm{n}$ " to " $\mathrm{t}$ " in the word quanto. Next comes quilisma-scandicus flexus. This is where the melody reaches the sound do for the last time, then slowly descends to the final re on the word magis, where the copyist notes clivis with episeme, pes quadratus subbipunctis with episeme and attached to this group oriscus, suggesting that the next note will be lower. Indeed, the next sound is the lowest sound of the antiphon $d o$, on which the pronoun vos meaning "you" resounds (over an octave lower than Magister). The melody clearly shows us our place, that we should humble ourselves towards others. It will resound once more over the words alter alterius. Before that, however, we have the verb debetis, which rises slightly from the final sound towards $f a$ and sol. The stressed syllable - be is underlined by virga with episeme on the sound fa and clivis fa-sol. The words alter alterius mean "one to another," and more precisely "one (of two) to another (of two)."12 Once more the melody shows the relation between these two persons - the numeral alter is placed lower than alterius. It is also much less ornamented. It consists of only two single-note neumes: cephalicus on the sound $m i$ with the significative letter $i$, that is iusum, meaning descent down (another "humiliation"), and virga on the sound sol. Whereas the numeral alterius climbs from the dominant $l a$ to $s i$ on the syllable al-and

11 M. Sławecki, Gtówne aspekty śpiewu gregoriańskiego, in: M. Bornus-Szczyciński, A. Nowak, M. Sławecki, Monodia, Warszawa 2008, p. 174 (Pieśń Polska).

12 A. Jougan, Alter, in: A. Jougan, Stownik kościelny tacińsko-polski, Warszawa 1992. 
then descends slowly (clivis with episeme la-sol on the syllable te-) to the sound $m i$ on the syllable -us (clivis with episeme). The melody on the following words lavare pedes, meaning "to wash the feet", runs low around the final re. Here again, we can relate the pitch of the melody to the "humble" gesture of washing the feet. After all, in the time of Christ, this gesture was appropriate for servants and slaves. ${ }^{13}$ The verb lavare begins with the lowest note of the melody - do, similar to the pronoun vos. Then it slowly 'waves' with the sounds mi-re-fa-mi to end with the final $r e$ in the noun pedes (two tractuli closing the phrase, similar to the word pedes closing the first clause on the dominant $l a$ ).

It seems very clear then that the music rhetoric noted by the copyist of CH-SGs 390 is subordinated to the word and its exegesis. The restored melody in the GrN is confirmed by diastematic records in later manuscripts, especially in the $12^{\text {th- }}$ -century codex ms. 807 from Graz (A-Gu 807), which precisely shows the pitches on four staff lines signed successively $d, f, a$ and $c$, and for the most part in the $11^{\text {th }}$-century Gradual of Gaillac (F-Pn lat. 776). ${ }^{14}$

Let us then look at how the antiphon "Si ego Dominus et Magister" was recorded in PL-Kk 43. Contrary to the version written in GrN, the scriptor of PL-Kk 43, Stanisław of Buk, ${ }^{15}$ begins the antiphon's melody with the sound $f a$, not $m i$. The first phrase on the words Si ego therefore is placed on the sounds fa-re-fa, not mi-re-mi. Next, like in GrN, the melody rises on the noun Dominus to the structural sound $l a$ and circles around it. It seems, then, that the modal structure of the antiphon may be the same in both notations. The structural sound la emphasizes the importance of the noun Dominus, although the notator of PL-Kk 43 does not record the repercussions on the last syllable of this word. Instead, he notes a single punctum. Rhomboidal punctum is the basic unit of musical notation in Jan Olbracht Gradual ${ }^{16}$. In the notation of antiphon "Si ego Dominus et Magister" there are only five complex neumes (composed of punctum and virga): pes, torculus, clivis, multi-sound climacus and two liquescences. We can, therefore, notice a certain reduction comparing to the version noted in $\mathrm{CH}-\mathrm{SG} 390 .{ }^{17}$ On the

\footnotetext{
13 See D. Kwiatkowski, Paschalny wymiar obrzędu „Mandatum” podczas Mszy Wieczerzy Pańskiej Wielkiego Czwartku, „Liturgia Sacra” 18 (2012) nr 2, p. 345-346.

14 See Fig. 1. Comparative table in Appendices.

15 See M. Popowska, Jan Olbracht Gradual, p. 173.

16 See M. Popowska, Jan Olbracht Gradual, p. 168.

17 The phenomenon of melodic simplifications and reduction of multi-note neumes and repercussions in Jan Olbracht Gradual are described, among others, by Tomasz Głuchowski and Paweł Kasprzyk. See T. Głuchowski, Przeksztatcenia melodyczne w notacji rękopisu nr 44 Archiwum Krakowskiej Kapituty Katedralnej na przyktadzie introitu “Introduxit vos”, „Pro Musica Sacra" 17 (2019), p. 203-219 and P. Kasprzyk, Graduat "Priusquam te formarem” z Graduatu
} 
conjunction et the melody descends back to the sound $f a$ (in $\mathrm{GrN}$ to $s o l$ ), then ascends to the structural sounds $l a$ and $d o$ on the first syllable of the noun $\mathrm{Ma}$ gister. Already at this point, we can see in the version of the antiphon in PL-Kk 43 a clear tendency to boldly use larger intervals between individual notes. In the version in $\mathrm{GrN}$, the distances between the notes are narrow and the melody smoothly moves up and down, mainly in intervals of seconds. The highest recorded interval is a minor third, which appears only six times in the places rhetorically significant, when the melody moves from or to a structural degree (on the words Dominus and vobis), and when the register of the melody is changed according to the significance of the text (on the words quanto magis, debetis and alter alterius lavare). While in the late medieval notation of the melody in PL-Kk 43, there are already three thirds only on the first words Si ego Dominus, and then a triad fa-la-do on the word Magister, which indicates a different aesthetics of the recorded chant.

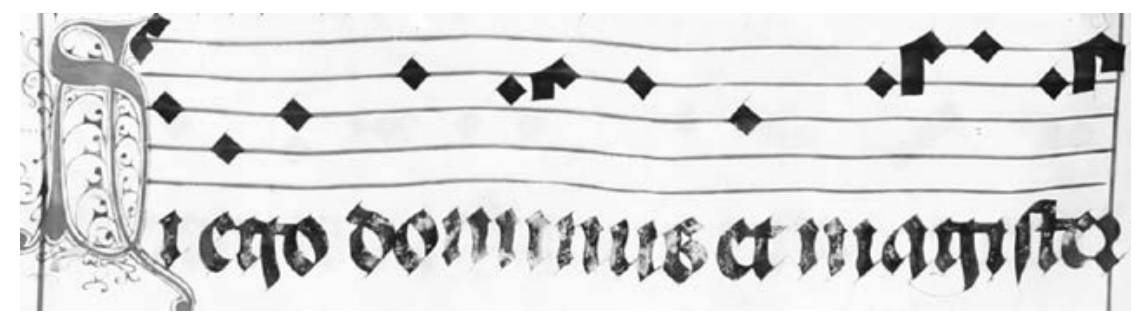

1. Intervals on the phrase "Si ego Dominus et Magister" in PL-Kk 43 (AKKK, Ms. 43, f. 197)

The notator of the version of the chant recorded in PL-Kk 43 develops the melody in a different way than we observe in older manuscripts, where the melody is more focused and precisely directed to emphasize the sung text. The variant from PL-Kk 43 transmits rather different musical sensitivity. Larger intervals are preferred, especially thirds, which seem to be the main means of building tension in the melody. This phenomenon is clearly visible on the example of the words alter alterius, where the melody jumps from $m i$ to sol and then to la and do. Such an ambitus on just four notes is unheard of in the older layer of Gregorian chant. In the GrN notation, we have a liquescence on the sound mi, a jump up a third on sol and a gentle transition to pes la-si. While, as we can see, the scriptor from Wawel notes only the sounds mi-sol and then pes on the sounds la-do.

Jana Olbrachta w swietle “authenticum fontium gregorianum”, „Pro Musica Sacra” 18 (2020), p. $155-166$. 


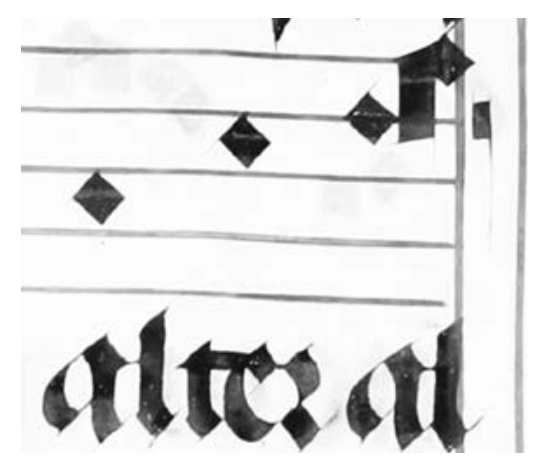

2. Ambitus of the melody on words alter al(terius) in PL-Kk 43 (AKKK, Ms. 43, f. 197v)

It also seems that the melody of the antiphon recorded in PL-Kk 43 no longer follows the rhetoric of the text as closely as it is noted in CH-SGs 390, in part because of the square notation that does not convey such precise information about musical articulation as the adiastematic one. The difference from the older records of the antiphon can be seen in the example of the pronoun vester. The scriptor of PL-Kk 43 notes here the highest note of the melody - the upper $r e$, which is the ornament of the neuma pes subquadripunctis on the syllable ve-. In case of the restitution from $\mathrm{GrN}$, this sound adorned the syllable -ter emphasizing the importance of the noun Magister, thus its use was justified by the rhetoric of the text. In PL-Kk 43 the rhetoric justification of the ornament on word vester is not obvious.

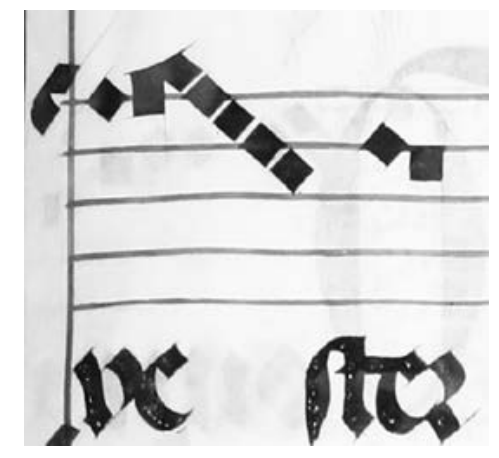

3. Ornament on the pronoun vester in PL-Kk 43 (AKKK, Ms. 43, f. 197v)

It can be seen in this example that the variant from PL-Kk 43 does not possess this precise logic of melodic exegesis contained in Sankt Gallen's records, and the notation serves primarily to indicate the melody. We can draw the same conclusions 
for the pronoun quanto in the phrase quanto magis. In the version in $\mathrm{GrN}$, the rhetoric of the phrase is refined in a melody (la-sol-la-si-do-si), while in PL-Kk 43 the notator reduces the melody to just three sounds $l a-l a-d o$.

Nevertheless, it can be concluded that in the first part of the antiphon, the melody to words "Si ego dominus et magister vester lavi vobis pedes" has a quite similar course as in the version from $\mathrm{GrN}$ and both are undoubtedly variants of the same melody. The structural degrees are preserved, although the melody in PL-Kk 43 has its specific character, different from the version from GrN. This character develops even more in the second part of the antiphon, where the melodic differences between the two versions are fundamental, as they concern structural degrees. On the words quanto magis, as described above, the melody in PL-Kk 43 immediately goes a third up from la to do on the pronoun quanto and then down a fourth on the syllable ma-gis and descends towards the sound do in flowing climacus with the first pulsating sound on the pronoun vos. At this point, the melodies of the two versions diverge when it comes to modal structure.

On the words vos debetis alter alterius lavare pedes, the melody in the version written in $\mathrm{GrN}$ revolves around the final $r e$, climbs to the sound $f a$, then onto la, to return in the cadence to the final re on the word pedes. Meanwhile, the variant written in PL-Kk 43 has the final mi, and the entire last phrase is shaped around this structural degree. The cadence itself on the words lavare pedes is shifted one tone higher than the version in $\mathrm{GrN}$. Thus, the modal layout of the chant changes from the first mode (authentic protus) to the fourth mode (plagal deuterus), which is built on structural sounds $m i$ and la. Interestingly, the psalm to the antiphon in PL-Kk 43 appears in turn in the third mode (authentic deuterus).

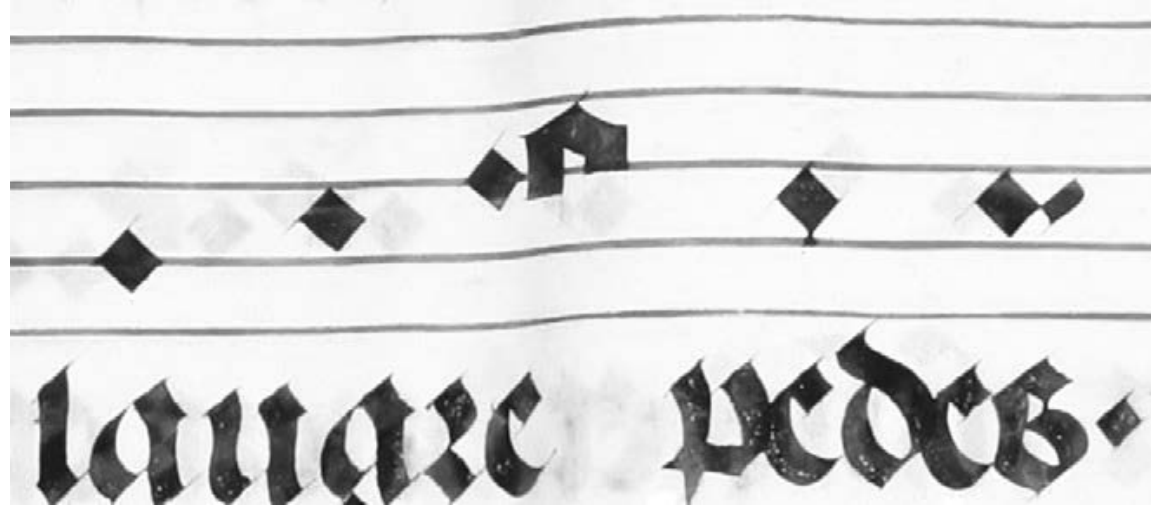

4. Cadence on the sound mi in PL-Kk 43 (AKKK, Ms. 43, f. 197v) 


\section{Conclusions}

The phenomenon of changing the tonal attribution of chants was not unknown in the Middle Ages. ${ }^{18}$ On one hand, it could result from the oral transmission of the repertoire, which caused transformations in melodies, on the other, it could be influenced by local preferences. ${ }^{19}$ This process mainly concerned the less stable repertoire of chants, such as antiphons and responsories of the Divine Office. ${ }^{20}$ It seems that we can also include in this category the antiphons of the Mandatum, celebrated in the Middle Ages outside the liturgy of the Mass. The version of the chant "Si ego Dominus et Magister" with the final $m i$ appears already in the $11^{\text {th }}$-century gradual from St. Yrieix (F-Pn lat. 903), while in neighbouring Gaillac this chant functioned with the final $r e$, as evidenced in gradual F-Pn lat. 776. A further comparison of the two records confirms the instability of the melody of the antiphon "Si ego Dominus et Magister", even in sources so closely "related" to each other. Research questions that could be posed include the presence of this inclination towards the final $m i$ also in later manuscripts. This variant must have gained popularity over time, as the chant version in fourth tone eventually appeared even in the Graduale Romanum (GR) from 1908. ${ }^{21}$ However, this question requires extensive research, going beyond the scope of this article. Also, the determination of the origin of the antiphon's version in PL-Kk 43 requires further research, considering later variants of the chant in manuscripts from all over Europe. This research would also allow to determine the degree of originality of the version of the antiphon in PL-Kk 43.

At the present stage of the analysis, it has been possible to confirm the identity of the melody of the antiphon "Si ego Dominus et Magister" recorded in Jan Olbracht Gradual. The study has shown that it is undoubtedly a variant of the melody transmitted by the oldest adiastemic manuscripts, such as Hartker Antiphonary, a melody that still functions in the liturgy of the Western Church. It was also possible to show the melodic changes in the version in PL-Kk 43, resulting from the development and constant "migration" of chants, as well as from the late medieval musical sensitivity. Primarily these transformations concern the change of relation between sounds, introducing larger intervals to the melody, especially thirds, and reducing the sounds between these intervals. The change of these

18 See J. Kubieniec, Secundum consuetudinem. Śpiew godzin kanonicznych w średniowiecznej metropolii gnieźnieńskiej, Kraków 2013.

19 See J. Kubieniec, Secundum consuetudinem, p. 137-138.

20 See J. Kubieniec, Secundum consuetudinem, p. 8.

21 See Fig. 1. Comparative table in Appendices. 
relations also results in a shift of the modus of the antiphon, accompanied by the change of the function of notation, aimed primarily at indicating the melody. The described phenomena undoubtedly show the changes that took place in Gregorian chant over the centuries. They picture vitality and constant evolution of the musical and liturgical repertoire, but also extraordinary richness of Gregorian chant that remains undiscovered. The example of the antiphon "Si ego Dominus et Magister" also shows how important it is to study one's own, local tradition of Gregorian chant, which grew out of European tradition, because knowing one's own roots remains an important element of human identity.

\section{Appendices}

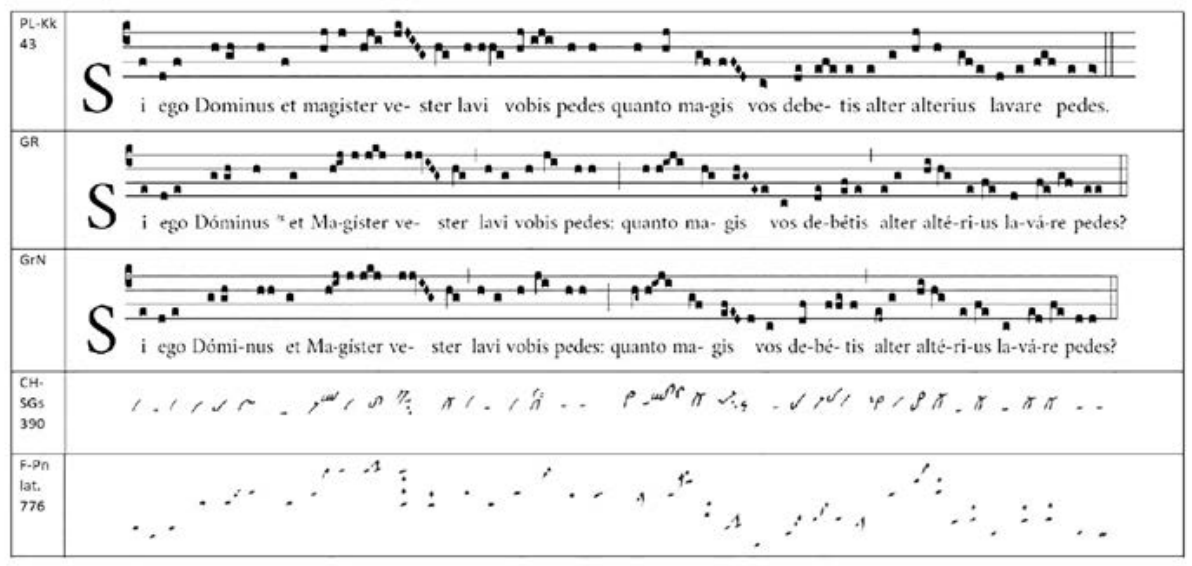

1. Comparative table. Antiphon "Si ego Dominus et Magister" 


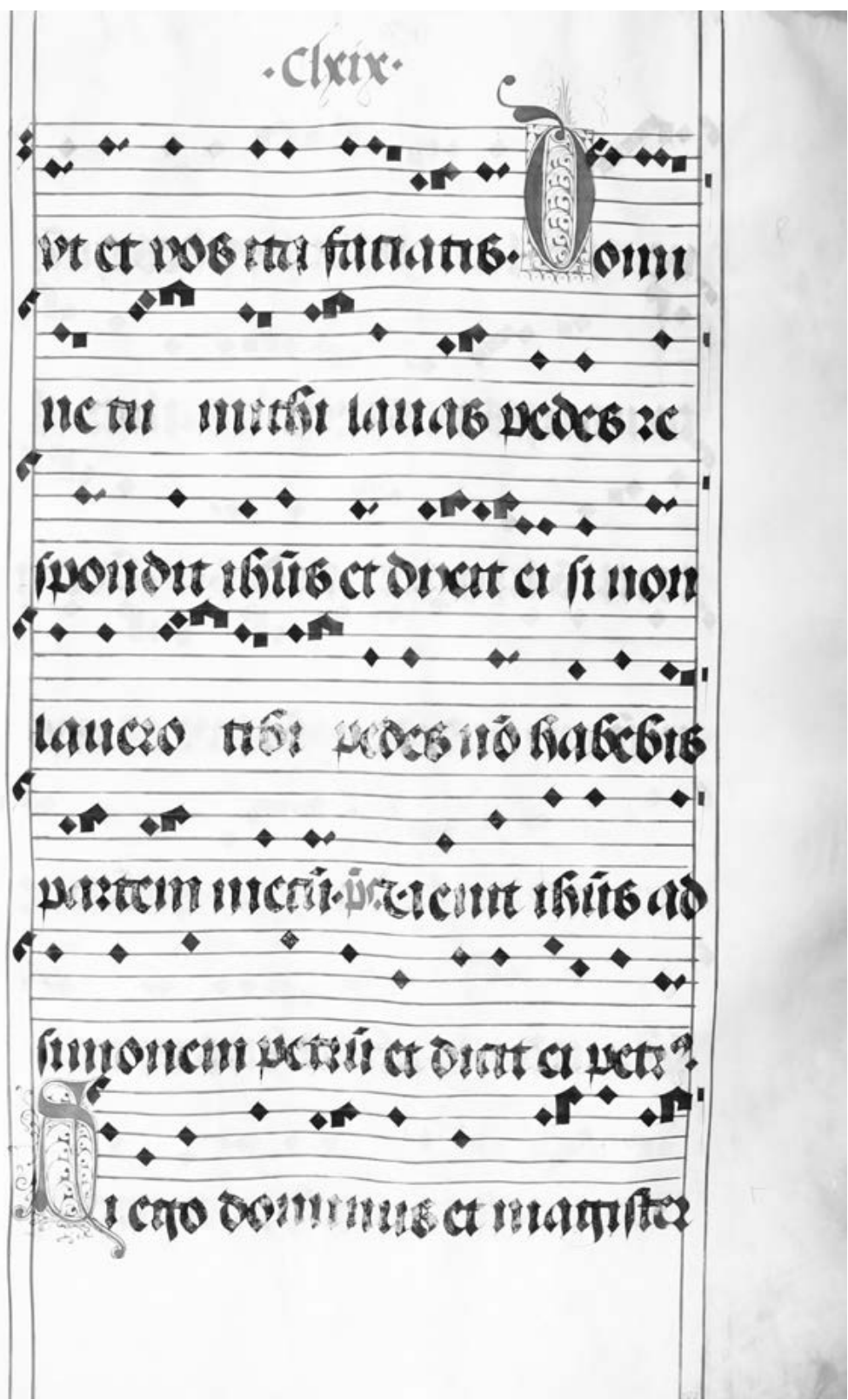




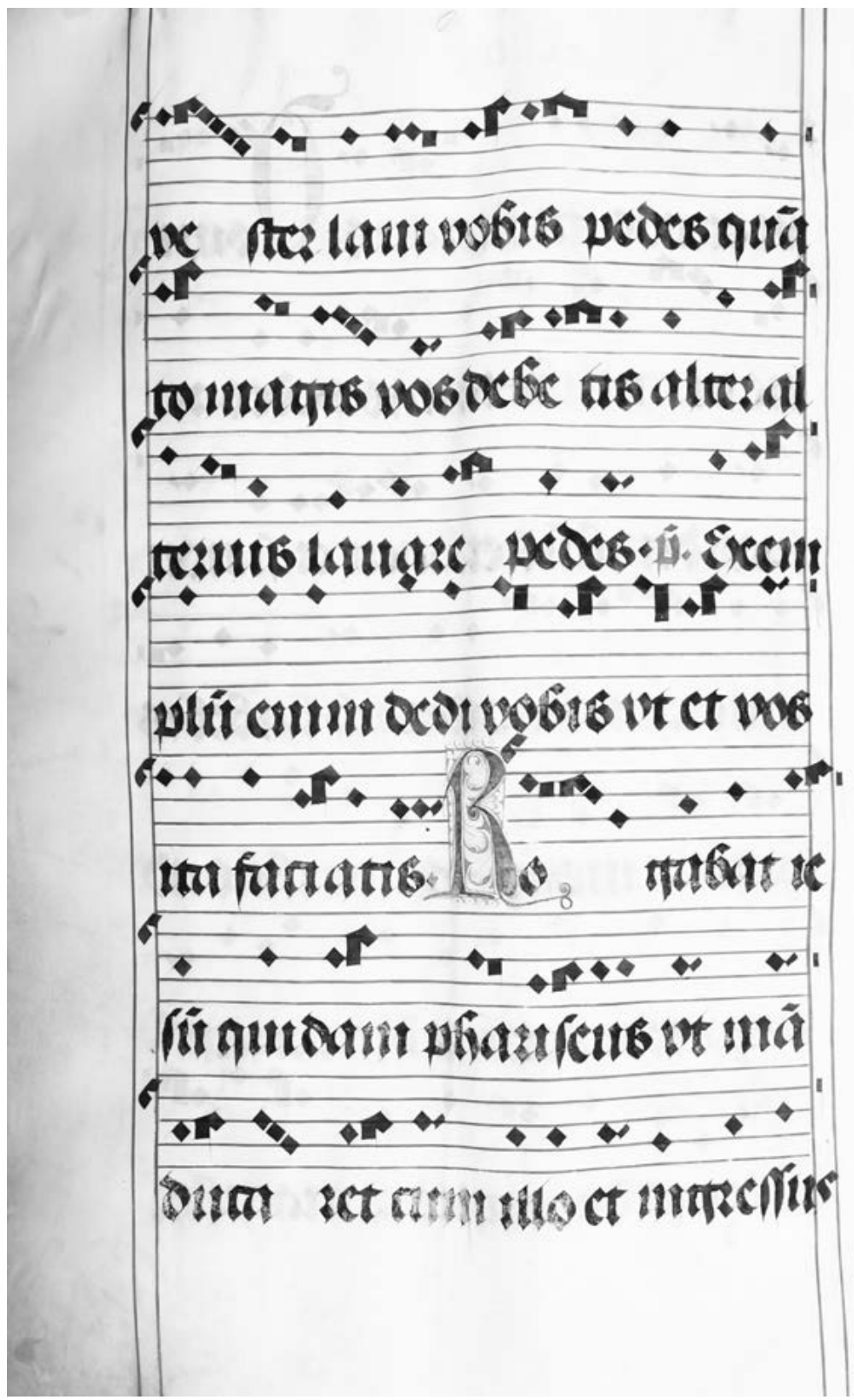




\begin{abstract}
Phenomenon of Melodic Changes in the late Medieval Notation of Jan Olbracht Giradual on the Example of Antiphon ad Mandatum "Si ego Dominus et Magister"
\end{abstract}

The article presents melodic transformations of the antiphon ad Mandatum "Si ego Dominus et Magister" recorded in one of the most valuable Polish monuments of the late Middle Ages, Jan Olbracht Gradual (PL-Kk 43, AKKK). The analysis of transformations was carried out on the basis of comparison with adiastematic notation of the discussed antiphon in Hartker Antiphonary (CH-SGs 390) and its melodic restitution in Graduale Novum. Conducted research led to establishing the identity of the version of the antiphon recorded in Olbracht Gradual and identifying basic differences from versions of the chant noted in older manuscripts, such as changes in the relationship between sounds, the use of larger intervals and change in tonal attribution of the antiphon.

Keywords: Jan Olbracht Gradual, Hartker Antiphonary, melodic transformations, Mandatum, antiphon, Sie ego Dominus et Magister

\begin{abstract}
Abstrakt
Przekształcenia melodyczne w późnośredniowiecznej notacji Graduału Jana Olbrachta na przykładzie antyfony ad Mandatum „Si ego Dominus et Magister"
\end{abstract}

W artykule przedstawiono przekształcenia melodyczne antyfony ad Mandatum "Si ego Dominus et Magister" zapisanej w jednym z najcenniejszych zabytków polskich późnego średniowiecza, Graduale Jana Olbrachta (Rkp. 43, AKKK). Analizę przekształceń przeprowadzono w oparciu o porównanie z zapisem adiastematycznym omawianej antyfony w Antyfonarzu Hartkera (CH-SGs 390) oraz jego restytucją melodyczną w Graduale Novum. W wyniku przeprowadzonych badań ustalono tożsamość wersji antyfony zapisanej w Graduale Olbrachta oraz wyłoniono podstawowe różnice względem starszych wersji zapisu śpiewu, takie jak zmiana relacji między dźwiękami, stosowanie większych interwałów oraz zmiana atrybucji tonalnej antyfony.

Stowa kluczowe: Graduał Jana Olbrachta, Antyfonarz Hartkera, przekształcenia melodyczne, Mandatum, antyfona, Si ego Dominus et Magister 


\section{Bibliography}

\section{Sources}

Graduale Albiense, Bibliothèque Nationale de France, ms. lat. 776, https://gallica.bnf.fr/ ark:/12148/btv1b84546727/f128.image (22.06.2021).

Graduale Novum, t. 2: De feriis et sanctis, Regensburg 2018.

Graduale Romanum, Sacrosanctae Romanae Ecclesiae de tempore et de sanctis, Roma 1908.

Graduale, Troparium et Prosarium ad usum Sancti Aredii, Bibliothèque Nationale de France, ms. lat. 903, https://gallica.bnf.fr/ark:/12148/btv1b9068069f/f153.image (22.06.2021).

Graduat Jana Olbrachta, t. 1: De Sanctis, Archiwum i Biblioteka Krakowskiej Kapituły Katedralnej, Ms. 43, facsimile.

Graz, Universitätsbibliothek, ms. 807: Graduale (Kolsterneuburg), http://143.50.26.142/ digbib/handschriften/Ms.0800-0999/Ms.0807/slides/092v.jpg (22.06.2021).

St. Gallen, Stiftsbibliothek, Cod. Sang. 390: Antiphonarium officii, https://www.e-codices. unifr.ch/fr/csg/0390/185 (22.06.2021).

The Bible, Revised Standard Version Catholic Edition, https:/www.biblegateway.com/ versions/Revised-Standard-Version-Catholic-Edition-RSVCE-Bible/ (29.03.2021).

\section{Literature}

Amiet R., Le Mandatum de Jeudi Saint XIIIe-XVIIIe siècles, “Études Gregoriennes” 29 (2001), p. $68-87$.

Cardine E., Semiologia gregoriańska, tłum. M. Kaziński, Kraków 2008.

Głuchowski T., Przeksztatcenia melodyczne w notacji rękopisu nr 44 Archiwum Krakowskiej Kapituty Katedralnej na przyktadzie introitu „Introduxit vos”, „Pro Musica Sacra” 17 (2019), p. 203-219.

Hiley D., Western Plainchant. A Handbook, Oxford 1995.

Kasprzyk P., Graduat "Priusquam te formarem" z Graduatu Jana Olbrachta w świetle "authenticum fontium gregorianum”, „Pro Musica Sacra” 18 (2020), p. 155-166.

Jougan A., Stownik kościelny tacińsko-polski, Warszawa 1992.

Kubieniec J., Secundum consuetudinem. Śpiew godzin kanonicznych w średniowiecznej metropolii gnieźnieńskiej, Kraków 2013.

Kwiatkowski D., Paschalny wymiar obrzędu Mandatum podczas Mszy Wieczerzy Pańskiej Wielkiego Czwartku, „Liturgia Sacra” 18 (2012) no. 2, p. 343-355.

Lewański J., Liturgiczne tacińskie dramatyzacje Wielkiego Tygodnia XI-XVI w., Lublin 1999. Miazga T., Graduat Jana Olbrachta. Studium muzykologiczne, Graz 1980.

Popowska M., Jan Olbracht Gradual from the Archives of the Wawel Cathedral. Physical description, „Edukacja Muzyczna” 13 (2018), p. 183-207, http://cejsh.icm.edu.pl/ 
cejsh/element/bwmeta1.element.mhp-624d66e0-ef05-4aef-85f0-7e88977f6e0c (25.06.2021).

Praßl F.K., Kodeks Hartkera (CH-SGs 390/391) - genialna szkota retoryki w stużbie teologii liturgicznej, „Pro Musica Sacra” 17 (2019), p. 43-61.

Sławecki M., Gtówne aspekty śpiewu gregoriańskiego, in: M. Bornus-Szczyciński, A. Nowak, M. Sławecki, Monodia, Warszawa 2008, p. 103-216. 